\title{
PERBANDINGAN DAYA ANTIQUORUM SENSING EKSTRAK N-HEKSAN, ETIL ASETAT DAN METANOL KULIT BATANG KRANGEAN (Litsea cubeba (Lour.) Pers.) TERHADAP Pseudomonas aeruginosa
}

\author{
Tho'atun Ma'rufah ${ }^{1^{\star}}$, Triana Hertiani $^{2}$, Hady Anshory $\mathrm{T}^{1}$ \\ ${ }^{1}$ Prodi Farmasi Fakultas MIPA Universitas Islam Indonesia \\ ${ }^{2}$ Fakultas Farmasi Universitas Gadjah Mada \\ *e-mail: thoatunmarufah@gmail.com
}

\begin{abstract}
ABSTRAK
Quorum sensing adalah suatu bentuk komunikasi bakteri yang membantu mengatur perilaku koloni bakteri. Quorum sensing merupakan mekanisme komunikasi berdasarkan ekspresi gen dan populasi bakteri yang mempengaruhi perkembangan biofilm, pompa effluks, produksi toksin, dan faktor virulen lainnya. Quorum sensing inhibitor mengurangi patogenisitas organisme, mengurangi sifat virulen organisme, dan membantu sistem imun untuk membersihkan infeksi bakteri. Quorum sensing inhibitor dapat dikombinasi dengan antibiotik untuk membersihkan patogen yang persisten. Minyak atsiri kulit batang Krangean (Litsea cubeba) diketahui dapat menghambat pertumbuhan bakteri dan pembentukan biofilm Streptococcus mutans. Karena quorum sensing berperan dalam pembentukan biofilm maka dilakukan penelitian aktivitas daya antiquorum sensing kulit batang Krangean terhadap Pseudomonas aeruginosa. Penentuan kadar hambat minimal dari ekstrak $n$-heksan, etil asetat, dan metanol dilakukan dengan metode mikrodilusi. Dari hasil penelitian, didapatkan hasil bahwa ekstrak etil asetat merupakan ekstrak yang paling aktif terhadap Pseudomonas aeruginosa dengan kadar hambat minimal $8 \mu \mathrm{g} / \mu \mathrm{l}$. Ekstrak aktif etil asetat kemudian diuji daya antiquorum sensing dengan metode sumuran. Hasilnya menunjukkan bahwa ekstrak aktif etil asetat dengan loading sampel $25 \mathrm{mg}$ per sumuran, memiliki aktivitas antibakteri dan hambatan produksi pioverdin. Senyawa aktif diidentifikasi dengan KLT kemudian dilakukan uji bioautografi. Active compound group was unable to be determined by TLC then bioautography assay. Golongan senyawa yang terdapat di dalam ekstrak etil asetat yaitu alkaloid dan fenolik.
\end{abstract}

Kata kunci : Krangean, Pseudomonas aeruginosa, quorum sensing

\begin{abstract}
Quorum sensing is a bacterial cell to cell communication that help in controling bacterial colony behaviour. Quorum sensing is a communication mechanism based gene expression and population which influences biofilm development, efflux pump, toxin production, and other virulence factor. Quorum sensing inhibitor reduces organism pathogenicity, reduces organism virulence and helps immune system to eradicate bacterial infections. Quorum sensing inhibitor in combination with antibiotic can eradicate persistent pathogen. Essential oil of Krangean (Litsea cubeba) bark is known to inhibit bacterial growth and biofilm forming of Streptoccus mutans. Considering that quorum sensing mechanism plays an important role in biofilm forming, a research to explore the antiquorum sensing potency of Krangean bark towards Pseudomonas aeruginosa was undertaken. Determination of minimal inhibitory concentrations of $n$ hexane, ethyl acetate and methanol extract were undertaken by microdilution method. Based on the research, the ethyl acetate extract was the most active extract against Pseudomonas aeruginosa with minimal inhibitory concentration $8 \mu \mathrm{g} / \mu \mathrm{l}$. Therefore this extract was subjected to be tested for its antiquorum sensing activity by using diffusion method. The result showed that ethyl acetate extract with loading sample $25 \mathrm{mg} /$ well has antibacterial activity and pioverdin inhibition production. Active compound group was unable to be determined by TLC then bioautography assay. Compounds detected in ethyl acetate extract were alkaloid and phenolic.
\end{abstract}

Keywords : Krangean, Pseudomonas aeruginosa, quorum sensing 


\section{PENDAHULUAN}

Quorum sensing merupakan mekanisme komunikasi bakteri berdasarkan ekspresi gen berdasarkan populasi yang mempengaruhi perkembangan biofilm, pompa effluks, produksi toksin, dan faktor virulen lainnya. Jika dalam lingkungan hanya ada satu sel bakteri maka hanya akan mengeluarkan molekul quorum sensing yang sedikit. Ketika populasi sel mencapai konsentrasi tertentu maka molekul quorum sensing yang dihasilkan juga tinggi (Bassler, 1999).

Pseudomonas aeruginosa memproduksi beberapa senyawa seperti eksotoksin, piosianin, dan enzim. Eksotoksin yang dihasilkan adalah eksotoksin A yang dapat mengganggu sintesis protein dan menyebabkan kematian sel. Piosianin adalah pigmen biru-hijau yang dapat membunuh bakteri lain (bakterisidal) (Driscoll, et al., 2007). Selain itu, $P$. Aeruginosa menghasilkan pioverdin yang menjadikan bakteri ini dapat berfluoresens kehijauan fluoresensi kehijauan (Brooks, et al., 2008). Enzim yang dihasilkan seperti alkaline protease, elastase, dan protease lainnya dapat digunakan untuk..yang digunakan untuk mendegradasi protein bakteri lain. Enzim lain yang dihasilkan oleh bakteri tersebut adalah eksoenzim yang dapat merusak sel inang dan menyebabkan kematian. Ada 4 eksoenzim yaitu Ekso S, Ekso T, Ekso U, dan Ekso Y (Chopra, et al., 2001).

Selain bisa merusak inang, $P$. aeruginosa juga memiliki mekanisme perlindungan. $P$. aeruginosa memiliki pompa unik yang digunakan untuk mengeluarkan senyawa atau molekul berbahaya yang masuk ke dalam sel bakteri sebelum kerusakan terjadi. Pompa ini dapat mengeluarkan muka pompa effluks MexABOmpM (Bassler, 1999).

Biofilm adalah suatu mekanisme perlindungan bakteri dari bahaya luar seperti antibiotik. Biofilm merupakan kumpulan bakteri pada suatu permukaan dan tertutup oleh suatu matriks dari polisakarida primer (Donlan, 2002). Bakteri dalam biofilm dapat membentuk pelindung luar berupa polimer ekstraseluler yang berfungsi sebagai filter dan memberi nutrisi untuk bakteri di dalamnya serta melindungi bakteri dari agen berbahaya dari luar seperti antibiotik (Donlan, 2002). Bakteri yang tumbuh dalam biofilm tersebut dapat resisten terhadap antibiotic (Vuong, et al., 2003). Biofilm dapat melindungi bakteri dari kerusakan akibat antibiotik sehingga konsentrasi antibiotik perlu ditingkatkan 100-1000 kali lipat (Costerton, et al., 1994). Quorum sensing dapat menyebar luas dan meningkatkan pembentukan biofilm misalnya pada kasus sistik fibrosis dan infeksi pada mata (Rumbaugh, et al., 2000 dan Costerton, et al., 2001). Secara teori, quorum sensing inhibitor mengurangi patogenisitas organisme, mengurangi sifat virulen organisme, dan membantu sistem imun untuk membersihkan infeksi bakteri (Nagy, 2010). Salah satu tanaman tradisional Indonesia yang banyak dimanfaatkan oleh masyarakat adalah Krangean (Litsea cubeba). Di Indonesia, secara tradisional minyak kulit batang Krangean digunakan untuk sebagai obat kejang otot atau urat (Mardisiwoyo, 1986). Di Jawa Timur, kulit batang Krangean digunakan untuk parem (Susianti, 1996). Minyak atsiri dari buah $L$. cubeba, diketahui memiliki aktivitas antibakteri pada bakteri Gram positif maupun 
negative negatif (Daniel, 2005). Minyak atsiri buah $L$. cubeba dapat menghambat bakteri Pseudomonas aeruginosa (Mulia, 2000). Minyak atsiri kulit batang L. cubeba dapat menghambat pertumbuhan plankton plankton dan pembentukan biofilm pada Streptococcus mutans dengan kadar $\mathrm{IC}_{50}$ 0,010\% (Hertiani, et al., 2011). Karena minyak atsiri kulit batang Krangean dapat menghambat pembentukan biofilm pada Streptococcus mutans dan quorum sensing mempengaruhi perkembangan biofilm maka perlu diteliti apakah kulit batang krangean (Litsea cubeba) memiliki aktivitas penghambatan quorum sensing pada Pseudomonas aeruginosa serta perbandingan daya antiquorum sensing ekstrak n-heksan, etil asetat, dan metanol dari kulit batang L. cubeba dalam upaya penelusuran senyawa aktifnya.

\section{METODE PENELITIAN}

Serbuk kulit batang krangean
didapat dari penyalur produk kesehatan
central health Central Health, n-heksan
teknis, etil asetat teknis, metanol teknis,
aquades, aquabides steril, etil asetat
proanalysis, DMSO (Dimethyl sulfoxide)
99,99\%, nutrient broth, Cetrimide Agar, fase
gerak, plat KLT, standar antibiotik
(seftazidim), MTT (3-(4,5-dime-thylthiazolyl-
2) - 2, 5-diphenyltetrazolium bromide),
phosphate buffer saline.

Alat yang digunakan antara lain cawan porselen, cutter, gunting, kain, gelas beker, pipet tetes, corong buchner, corong, kertas saring, kertas coklat, selotip, timbangan, mikroplate, mikropipet, yellow tip, blue tip, autoklaf, petridisk, LAF (Laminar air flow), sinar UV 254 dan $366 \mathrm{~nm}$, kompor listrik, waterbath, rotary evaporator, perforator, jangka sorong.

Adapun cara penelitiannya sebagai berikut :

\section{Determinasi Tanaman dan identifikasi serbuk simplisia}

Tanaman yang akan dibuat menjadi simplisia dideterminasi terlebih dahulu dengan buku Flora of Java. Simplisia diuji organoleptis dan di uji secara mikroskopik.

\section{Maserasi Bertingkat}

Penyiapan ekstrak dilakukan
dengan cara maserasi. Serbuk $500 \mathrm{~g}$
direndam dengan n-heksan dengan
perbandingan pelarut: simplisia $(5: 1)$ selama
24 jam, sambil sesekali diaduk. Filtrat dikumpulkan dan diuapkan. Ampas dikeringkan lalu direndam lagi dengan $\mathrm{n}$ heksan selama 24 jam. Maserasi dengan $n$ heksan dilakukan sampai jernih. Ampas yang dikeringkan setelah maserasi dengan $\mathrm{n}$ heksan, dimaserasi lagi dengan etil asetat sampai jernih kemudian dimaserasi dengan metanol sampai jernih. Hasil dari maserasi bertingkat didapat ekstrak $n$-heksan, etil asetat, dan metanol, kemudian rendemen masing-masing ekstrak dihitung terhadap bobot keringnya.

\section{Penentuan Kadar Hambat Minimal (KHM)}

Ekstrak kental, diencerkan dengan DMSO 20\% lalu dibuat konsentrasinya menjadi $20 \mu \mathrm{g} / \mu \mathrm{l}$. Ekstrak, media nutrient broth, dan suspensi bakteri yang sudah setara kekeruhannya dengan standar Mc Farland I (1,5 x 10 $\left.0^{8} \mathrm{CFU} / \mathrm{ml}\right)$ dimasukkan ke dalam well microplate sebanyak $100 \mu \mathrm{l}$. Dibuat konsentrasi ekstrak 8, 4, 2, $1 \mu \mathrm{g} / \mu \mathrm{l}$. 
Dibuat pula kontrol media, kontrol media yang ditambah bakteri, kontrol antibiotik (antibiotik seftazidim + media + bakteri), dan kontrol ekstrak (ekstrak + media). Microplate diinkubasi pada suhu $36,6^{\circ} \mathrm{C}$ selama $18-24$ jam. Setelah diinkubasi, tiap well microplate yang ditambahkan bakteri, diberi reagen MTT sebanyak $5 \mu$ kemudian diinkubasi pada suhu $36,6^{\circ} \mathrm{C}$ selama 4 jam. Adanya pertumbuhan bakteri, ditandai dengan terbentuknya warna ungu sedangkan tidak adanya pertumbuhan bakteri ditandai dengan terbentuknya warna kuning.

\section{Uji Daya Antiquorum Sensing (Nagy, 2010)}

Media Agar dibuat dengan cara menuang medium Cetrimide Agar steril $50^{\circ} \mathrm{C}$ sebanyak $30 \mathrm{ml}$ ke dalam cawan petri dengan ukuran diameter $14 \mathrm{~cm}$ dan dibiarkan memadat. Medium cetrimide agar steril $50^{\circ} \mathrm{C}$ sebanyak $10 \mathrm{ml}$ diinokulasi dengan bakteri uji Pseudomonas aeruginosa yang kekeruhannya setara dengan larutan Mc Farland I (1,5 x $\left.10^{8} \mathrm{CFU} / \mathrm{ml}\right)$ sebanyak $100 \mu \mathrm{l}$ secara aseptis dituang ke atas media cetrimide tadi yang sudah memadat, kemudan dibiarkan sampai memadat. Media agar yang memadat dibuat sumuran dengan bantuan perforator diameter $8 \mathrm{~mm}$. Ekstrak yang aktif diencerkan dengan DMSO $10 \%$, dibuat kadar $250 \mu \mathrm{g} / \mu \mathrm{l}$ kemudian dimasukkan ke dalam tiap-tiap sumuran sebanyak 25, 50, $100 \mu \mathrm{l}$. Dibuat pula kontrol pelarut dan dimasukkan ke dalam sumuran sebanyak 25, 50, $100 \mu$ l. Petridisk diinkubasi pada suhu $36,6^{\circ} \mathrm{C}$ selama 24 jam. Aktivitas antiquorum sensing dapat diamati secara visual berupa zona yang buram (opaque) dilanjutkan dilihat di sinar UV 366 nm sedangkan adanya aktivitas antibakteri dapat diamati berupa zona jernih (transparan). Diukur besarnya zona buram dengan jangka sorong.

\section{Uji Bioautografi}

Ekstrak aktif kulit batang krangean dilarutkan ke dalam etil asetat dengan konsentrasi $250 \mu \mathrm{g} / \mu \mathrm{l}$ kemudian dilakukan penotolan sediaan uji dengan penotolan sediaan uji pada lempeng KLT silika gel 60 $\mathrm{F}_{254}$ dengan microsyringe sebanyak $0,5 \mu \mathrm{l}$ dengan jarak $1,5 \mathrm{~cm}$ dari tepi bawah sebanyak 8 totolan yang digunakan untuk uji bioautografi..kali yaitu untuk uji bioautografi, dan uji identifikasi kandungan senyawa. Lempeng KLT dikembangkan dengan larutan pengembang yang sesuai, dibiarkan sampai batas $0,5 \mathrm{~cm}$ dari tepi atas lempeng. Lempeng dikeluarkan dari bejana dan diangin-anginkan sampai cairan pengelusinya menguap. Kemudian dipotong tiap bagian lalu dilakukan pengamatan secara visual, pengamatan dengan sinar UV $254 \mathrm{~nm}$ dan UV 366 nm, diberi pereaksi semprot $\mathrm{FeCl}_{3}$, anisaldehid $\mathrm{H}_{2} \mathrm{SO}_{4}$, Dragendorf, $\mathrm{KOH}$ etanolik, dan $\mathrm{AICl}_{3}$. Lempeng KLT yang telah dielusi diletakkan diatas permukaan medium agar yang sudah diinokulasi dengan bakteri uji dengan posisi lapisan silika menempel pada medium. Lempengan dibiarkan kontak dengan medium agar selama 30 menit, kemudian lempengan diambil dengan hati-hati dan cawan petri diinkubasi pada suhu $36,6^{\circ} \mathrm{C}$ selama 18-24 jam. Zona buram diamati dan ditentukan bercak yang mempunyai aktivitas antiquorum sensing. 


\section{HASIL DAN PEMBAHASAN}

\section{Identifikasi serbuk simplisia}

Karena bahan yang diperoleh sudah berupa serbuk, maka perlu dipastikan serbuk simplisia benar-benar kulit batang krangean. Serbuk kulit batang krangean berwarna coklat tua, berbau khas, dan memiliki rasa pahit. Hasil uji mikroskopik serbuk dibandingkan dengan farmakope herbal
Indonesia. Hasil dari uji mikroskopik dapat dilihat di gambar 1 .

Dalam farmakope herbal Indonesia menyebutkan bahwa dalam simplisia krangean berwarna kecoklatan, bau khas, rasa agak pedas dan agak pahit. Fragmen pengenal adalah serabut floem, serabut perisikel, jaringan gabus berdinding tipis, sel bau, serabut sklerenkim dengan sel batu dan kristal oksalat bentuk roset (Anonim, 2011).
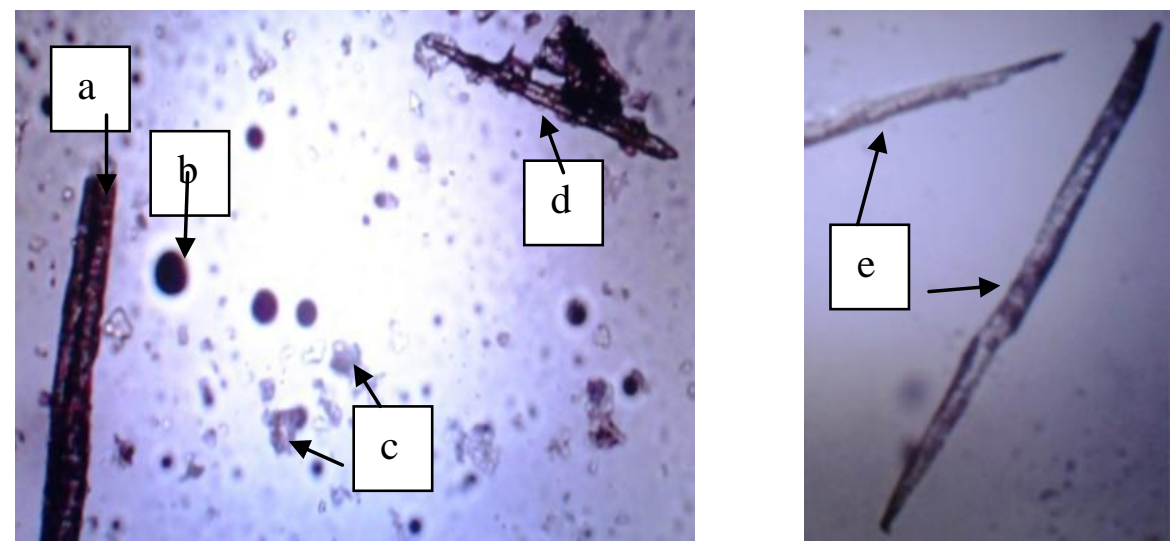

Gambar 1. Hasil uji mikroskopik serbuk kulit batang krangean

Keterangan : dengan perbesaran 10 kali, (a) Serabut perisikel (b) sel batu (c) kristal oksalat bentuk roset (d) serabut sklerenkim denaan sel batu (e) serabut floem

Dari gambar 1, dalam serbuk kulit batang krangean terdapat serabut perisikel, sel batu, kristal oksalat berbentuk roset, Evaluasi ekstrak kulit batang krangean serabut sklerenkim dengan sel batu dan serabut floem. Berarti dapat disimpulkan bahwa serbuk simplisia yang dipakai adalah kulit batang krangean.

Maserasi bertingkat serbuk kulit batang krangean ditujukan agar mendapat ekstrak yang sifatnya nonpolar, semipolar dan polar. Ekstrak kental yang didapat dihitung rendemennya terhadap bobot kering dan diamati sifat fisiknya (tabel 1). 
Tabel 1. Hasil pengamatan fisik dan rendemen ekstrak kulit

\begin{tabular}{llrr}
\hline Ekstrak & Sifat fisik & Bobot ekstrak & Rendemen \\
\hline n-heksan & Ekstrak kental berwarna hijau tua & & \\
Etil & kehitaman, bau khas & $10,28 \mathrm{~g}$ & $2,06 \%$ \\
asetat & Ekstrak kental, lengket, berwarna coklat tua & $18,17 \mathrm{~g}$ & $3,82 \%$ \\
Metanol & Ekstrak kental berwarna coklat tua & $20,90 \mathrm{~g}$ & $10,33 \%$ \\
\hline
\end{tabular}

Tabel 2. Hasil uji mikrodilusi ekstrak

\begin{tabular}{|c|c|c|c|c|c|}
\hline \multicolumn{2}{|c|}{ Kelompok perlakuan } & \multirow[t]{2}{*}{$8 \mu \mathrm{g} / \mu \mathrm{l}$} & \multirow[t]{2}{*}{$4 \mu \mathrm{g} / \mu \mathrm{l}$} & \multirow[t]{2}{*}{$2 \mu \mathrm{g} / \mu \mathrm{l}$} & \multirow[t]{2}{*}{$1 \mu \mathrm{g} / \mu$} \\
\hline Ekstrak & replikasi & & & & \\
\hline \multirow[t]{3}{*}{ n-heksan } & 1 & + & + & + & + \\
\hline & 2 & + & + & + & + \\
\hline & 3 & + & + & + & + \\
\hline \multirow[t]{3}{*}{ Etil asetat } & 1 & - & + & + & + \\
\hline & 2 & - & + & + & + \\
\hline & 3 & - & + & + & + \\
\hline \multirow[t]{3}{*}{ Metanol } & 1 & + & + & + & + \\
\hline & 2 & + & + & + & + \\
\hline & 3 & + & + & + & + \\
\hline
\end{tabular}

Keterangan (-) kuning (+) ungu

Dari hasil \% rendemen ekstrak n-heksan memiliki \% rendemen yang paling kecil sedangkan \% rendemen ekstrak metanol yang paling besar. Dalam $\mathrm{Hu}$ et al (2011), ekstrak etanol 70\% buah krangean yang diekstraksi dengan soxhlet memiliki kandungan $d$-limonen (8,52\%), $\alpha$-citral $(26,15 \%), \quad \beta$-citral $(33,16 \%)$ dan $\beta$-pinen, sitronelal, linalool, $\alpha$-terpineol, $\alpha$-tujena, eugenol, dan a-pinena (Anonim 1980).

\section{Penentuan Kadar Hambat Minimal (KHM)}

Kadar hambat minimal adalah kadar terkecil suatu senyawa dapat menghambat pertumbuhan bakteri. Dalam penetuan KHM dengan metode mikrodilusi, tiap ekstrak dilarutkan dengan DMSO (Dimetil sulfoksida).

Kelebihan DMSO adalah memiliki kepolaran yang luas sehingga dapat melarutkan tiap ekstrak. Dipakai pelarut DMSO dengan konsentrasi $20 \%$, 
disesuaikan dengan yang tertera di metode supaya DMSO yang sudah dilarutkan dengan ekstrak tidak mempengaruhi hasil. DMSO $8 \%$ diketahui telah resisten terhadap Pseudomonas aeruginosa.

Penambahan MTT (3-(4,5dimethylthiazolyl-2)-2,5-diphenyl tetrazolium bromide) bertujuan untuk mengetahui adanya pertumbuhan bakteri dengan terbentuknya warna ungu akibat adanya pengurangan warna kuning MTT oleh metabolit aktif sel oleh aksi enzim dehidrogenase sehingga terbentuk formazan (Ho, et al., 2010). Jika tidak tumbuh bakteri, maka akan terbentuk warna kuning. Hasil dapat dilihat pada tabel 2. Pada kontrol pelarut, DMSO $8 \%$ tidak memiliki aktivitas antibakteri. Jadi DMSO tidak mempengaruhi aktivitas antibakteri ekstrak aktif. Pada kontrol antibiotik, seftazidim dapat menghambat pertumbuhan bakteri Pseudomonas aeruginosa karena terbentuk warna kuning atau jernih.

Kontrol ekstrak digunakan sebagai pembanding terhadap kelompok perlakuan karena ekstrak memiliki warna dan sedikit keruh padahal MTT berwarna kuning. Jika Jika warna kontrol ekstrak sama hampir sama dengan perlakuan, dimungkinkan ekstrak tersebut memiliki aktivitas antibakteri.

Pada ekstrak n-heksan, dari empat konsentrasi ekstrak, semuanya menghasilkan warna ungu setelah penambahan MTT. Hal ini menunjukkan bahwa kemungkinan kadar hambat minimal ekstrak n-heksan kulit batang krangean terhadap Pseudomonas aeruginosa adalah lebih dari $8 \mu \mathrm{g} / \mu \mathrm{l}$ atau kemungkinan ekstrak n-heksan tidak memiliki aktivitas antibakteri. Dalam Hertiani et al (2011), minyak atsiri $L$. cubeba memiliki aktivitas antibakteri terhadap S. mutans dengan $\mathrm{MIC}_{90} \quad 0,06 \%$ (Hertiani, et al., 2011). Begitu pula pada ekstrak metanol, karena pada kadar $8 \mu \mathrm{g} / \mu \mathrm{l}$ juga berwarna ungu, kadar hambat minimal ekstrak metanol kulit batang krangean terhadap Pseudomonas aeruginosa adalah lebih dari $8 \mu \mathrm{g} / \mu \mathrm{l}$. Pada ekstrak etil asetat kadar $8 \mu \mathrm{g} / \mu \mathrm{l}$ terbentuk warna kuning yang berarti tidak ada pertumbuhan bakteri. Sedangkan ekstrak etil asetat dengan kadar $4 \mu \mathrm{g} / \mu \mathrm{l}, 2 \mu \mathrm{g} / \mu \mathrm{l}$, dan $1 \mu \mathrm{g} / \mu \mathrm{l}$ tidak memiliki aktivitas antibakteri karena terbentuk warna ungu setelah perlakuan. Jadi ekstrak yang paling aktif adalah ekstrak etil asetat dengan kadar hambat minimal $8 \mu \mathrm{g} / \mu \mathrm{l}$.

\section{Uji Aktivitas Daya Antiquorum Sensing}

Hasil penentuan KHM diketahui bahwa ekstrak etil asetat memiliki kadar hambat minimal $8 \mu \mathrm{g} / \mu \mathrm{l}$ terhadap Pseudomonas aeruginosa.

Uji difusi sumuran ini bertujuan untuk mengetahui aktivitas antiquorum sensing. Pada uji difusi digunakan dosis $25 \mathrm{mg}, 12,5$ $\mathrm{mg}$, dan 6,25 mg. Akan tetapi, zona yang terbentuk bukan zona buram /opaque namun zona jernih.

Hasil uji menunjukkan bahwa pada visibel tidak terlihat adanya zona opaque (buram) tetapi di UV 366 zona yang tidak berpendar lebih besar daripada zona jernih (tabel 3). Hal ini kemungkinan disebabkan adanya hambatan pembentukan senyawa pioverdin. Pioverdin menjadikan bakteri berfluoresensi kehijauan. Produksi senyawa pioverdin dipengaruhi antara lain oleh proses quorum sensing. Tetapi karena produksi piosianin tidak dihambat, perlu penelitian lebih lanjut untuk memastikan 
penghambatan quorum sensing. Jadi, penghambatan produksi pioverdin pada ekstrak etil asetat kulit batang Krangean dosis $25 \mathrm{mg} / \mathrm{sumuran}$.

memiliki aktivitas antibakteri dan

Tabel 3. Hasil uji aktivitas daya antiquorum sensing

\begin{tabular}{cccc}
\hline Dosis (mg) & Replikasi & $\begin{array}{l}\text { Zona jernih } \\
\text { (visual) }(\mathrm{mm})\end{array}$ & $\begin{array}{l}\text { Zona penghambatan } \\
\text { pioverdin (UV 366 nm) } \\
(\mathrm{mm})\end{array}$ \\
\hline \multirow{2}{*}{25} & 1 & 12,25 & 14,16 \\
& 2 & 10,11 & 10,37 \\
& 3 & 12,29 & 13,52 \\
\hline \multirow{2}{*}{12,5} & 1 & - & - \\
& 2 & - & - \\
\hline \multirow{2}{*}{6,25} & 3 & - & - \\
& 1 & - & - \\
& 2 & - & \\
& 3 & - & \\
\hline
\end{tabular}

Keterangan : diameter sumuran $8 \mathrm{~mm}$

Aktivitas penghambatan pioverdin dilihat zona tidak berpendar di UV 366

\section{Uji Bioautografi dan Identifikasi Senyawa Aktif}

Pada uji bioautografi dan identifikasi senyawa aktif, digunakan metode kromatografi lapis tipis dengan pereaksi semprot untuk identifikasi golongan senyawa aktif. Ekstrak etil asetat $250 \mu \mathrm{g} / \mu \mathrm{l}$ ditotolkan sebanyak 0,5 $\mu$ l yang setara dengan $125 \mu \mathrm{g}$, ke plat KLT dengan fase gerak kloroform : aseton $(7: 1)$

Uji bioautografi menunjukkan tidak ada aktivitas antiquorum sensing. Hal ini dikarenakan kadar ekstrak etil asetat pada plat KLT lebih kecil dibandingkan dosis yang diberikan saat metode difusi.

Pada metode difusi jumlah sampel yang diberikan adalah $25 \mathrm{mg}$ per sumuran, sedangkan pada bioautografi jumlah sampel sebesar 0,125 mg. Karena itulah, pada uji bioautografi tidak menunjukkan adanya aktivitas antiquorum sensing dan antibakteri. Kemungkinan lain, sampel tidak dapat berdifusi dengan baik sehingga dapat dicoba metode bioautografi overlay agar kontak mikroba dengan sampel lebih lama. Kemudian untuk identifikasi senyawa aktif ekstrak etil asetat krangean ditunjukkan pada tabel 4.

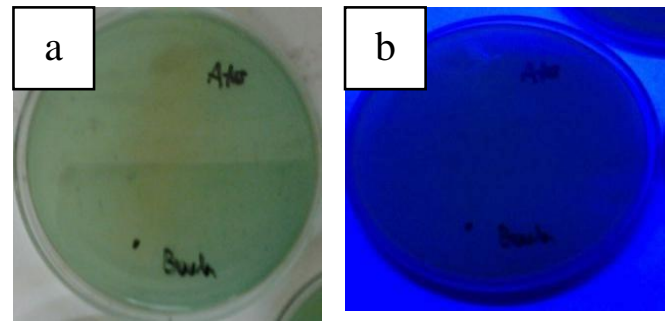

Gambar 2. Hasil uji bioautografi Keterangan : (a) visibel (b) UV 366 
Tabel 4. Profil KLT dan senyawa aktif

\begin{tabular}{|c|c|c|c|c|c|c|c|c|}
\hline \multirow[b]{2}{*}{$\begin{array}{c}\mathrm{hRf} \\
\text { visibel }\end{array}$} & \multirow[b]{2}{*}{$\begin{array}{l}\text { UV } \\
254\end{array}$} & \multirow[b]{2}{*}{$\begin{array}{l}\text { UV } \\
366\end{array}$} & \multicolumn{5}{|c|}{ Perubahan warna } & \multirow[b]{2}{*}{ Senyawa aktif } \\
\hline & & & $\begin{array}{c}\mathrm{KOH} \\
\text { etanolik }\end{array}$ & $\mathrm{FeCl}_{3}$ & $\begin{array}{c}\mathrm{AlCl} \\
3\end{array}$ & Dragendorf & $\begin{array}{l}\text { Anisaldehid } \\
\text { asam sulfat }\end{array}$ & \\
\hline 0 & $\sqrt{ }$ & - & - & - & - & - & - & - \\
\hline 12 & $\sqrt{ }$ & - & - & hitam & - & - & - & fenolik \\
\hline 22 & $\sqrt{ }$ & - & - & & - & $\begin{array}{l}\text { Coklat } \\
\text { oranye }\end{array}$ & - & alkaloid \\
\hline 37 & $\sqrt{ }$ & - & - & - & - & - & - & - \\
\hline 53 & $\sqrt{ }$ & - & - & - & - & - & - & - \\
\hline 58 & $\sqrt{ }$ & - & - & - & - & - & - & - \\
\hline 67 & $\sqrt{ }$ & - & - & - & - & - & - & - \\
\hline
\end{tabular}

Keterangan : $\sqrt{ }$ : berpendar

hRf pada bercak KLT setelah disemprot dengan $\mathrm{FeCl}_{3}$ dan dragendorf berdekatan. Beberapa/dua bercak/spot yang terlihat memiliki nilai $\mathrm{hRf}$ yang hampir sama Pada gambar 2 , bercak yang berubah warna berada pada bercak yang berdekatan juga. Hal ini terjadi karena pemisahan senyawa dengan KLT kurang sempurna. Dari tabel 4, kemungkinan senyawa yang ada di dalam ekstrak aktif etil asetat adalah alkaloid dan fenolik. Senyawa yang memiliki aktivitas antiqourum sensing juga tidak dapat diketahui karena hasil uji bioautografi tidak menunjukkan adanya antiquorum sensing dan antibakteri.

Dalam Zang et al (2012), isoquinolin alkaloid dalam ekstrak etanol 70\% kulit batang Litsea cubeba yaitu alkaloid (+)-N(methoxylcarbonyl)-N-nordicentrin, (+)-N(methoxylcarbonyl)-N-norpredi-centrine, (+)$\mathrm{N}$-(methoxylcarbony)- $\mathrm{N}$-norglaucine memiliki aktivitas antibakteri terhadap Staphyllococcus aureus (Yang, et al., 2010). Alkaloid dapat bersifat antibakteri karena dapat menghambat sintesis dinding sel yang akan menyebabkan sel lisis sehingga sel akan mati (Dweck, 2011). Senyawa fenol diketahui memiliki aktivitas antibakteri. Mekanisme aksi aktivitas antibakteri dari senyawa fenol adalah senyawa ini berinteraksi dengan sel bakteri melalui proses adsorpsi yang melibatkan ikatan hidrogen. Pada kadar rendah, terbentuk kompleks protein-fenol dengan ikatan yang lemah dan segera mengalami peruraian, diikuti penetrasi fenol ke dalam sel dan menyebabkan presipitasi serta denaturasi protein. Pada kadar tinggi fenol menyebabkan koagulasi protein dan sel membran mengalami lisis (Tyas, et al., 1999).

\section{KESIMPULAN}

Ekstrak kulit batang Krangean yang memiliki aktivitas antibakteri terhadap Pseudomonas aeruginosa adalah ekstrak etil asetat dengan kadar hambat minimal $8 \mu \mathrm{g} / \mu \mathrm{l}$. Ekstrak etil asetat kulit batang Krangean memiliki aktivitas antibakteri dan penghambatan produksi pioverdin terhadap Pseudomonas aeruginosa dengan metode 
difusi pada dosis dosis sampel 25 $\mathrm{mg} / \mathrm{sumuran}$. Senyawa yang terkandung di dalam ekstrak etil asetat kulit batang Krangean adalah alkaloid dan fenolik.

\section{DAFTAR PUSTAKA}

Anonim, 2008, Farmakope Herbal Indonesia, Departemen Kesehatan Republik Indonesia, Jakarta

Anonim, 2011, MTT Cell Proliferation Assay, at http://www.atcc.org (diakses tanggal 11 Juli 2013)

Basch, H., and Gadebusch, H., 1968, In Vitro Antimicrobial Activity of Dimethylsulfoxide, Appl. Microbiol., Vol 16 , No 12

Bassler, B. L., 1999, How Bacteria Talk to Each Other: Regulation of Gene Expression by Quorum Sensing, Curr. Opin. Microbiol., 2(6):582-87

Chopra, I., Roberts, M., 2001, Tetracycline Antibiotics: Mode of Action, Applications, Molecular Biology, and Epidemiology and Bacterial Resistance, Microbiol. Molecular Biology Review, 65.2.232-260

Costerton, J.W., Lewandowski, Z., DeBeer, D., Caldwell, D., Korber, D., James, G., 1994, Biofilms, the Customized Microniche, Journal Bacteriol., 176:2137-2142

Costerton, J.W., and Stewart, P.S., 2001, Battling Biofilms, Sct. Am., 7: 75-81

Daniel, M., 2005, Herbal TechnologyConcepts and Scope, Curr. Sci., 88(9): 1369-1370

Donlan R.M., 2002, Biofilms: Microbial Life on Surfaces, Emerging Infectious Diseases, 8(9):881-890

Driscoll J. A., Brody, S.L., Kollef, M.H., 2007, The Epidemiology, Pathogenesis and Treatment of Pseudomonas aeruginosa Infections, Drugs, 3:351368

Hertiani, T., Pratiwi, S.U.T., Irianto, I.D.K., Adityaningrum, D., Pranoto, B., 2011, Effect of Indonesian Medicinal Plants Essential Oils on Streptococcus mutans Biofilm,
Majalah Farmasi Indonesia, 22(3):174- 181

Hu, L., Wang, Y., Du, M., Zhang, J., 2011, Characterization of the Volatiles and Active Components in Ethanol Extracts of Fruits of Litsea cubeba (Lour.) by Gas ChromatographyMass Spectrometry (GC-MS) and Gas Chromatography- Olfactometry (GC-O), J. Med. Plants Research, Vol. 5(14):3298-3303

Jawetz, Melnick, Adelberg, 2008, Mikrobiologi Kedokteran, EGC, Jakarta, pp 266

Lamothe, R.G., 2009, Plant Microbial Agents and Their Effects on Plant and Human Pathogens. Int. J. Mol. Sci., 10: $3400-3419$

Mardisiwoyo, S.R., 1986, Cabe Puyang Warisan Nenek Moyang, Karya Weda, Jakarta, pp 636

Miller, M.B., and Bassler, B.L., 2001, Quorum Sensing in Bacteria, Annual Rev. Microbiol., 55:165-99

Mulia, L., 2000, Kajian Aktivitas Antimikroba Buah Andaliman (Zanthoxylum acanthopodicum) dan Antarasa (Litsea cubeba), Skripsi, Jurusan Teknologi Pertanian, Institut Pertanian Bogor, Bogor

Nagy, M.M., 2010, Quorum Sensing Inhibitory Activities of Various Folk Medicinal Plants and The Elucidation of The ThymeTetracycline Effect, disertasi, George State University, Atlanta

Raffa, R.B., lannuzzo, J.R., Levine, D.R., Saeid, K.K., Schwartz, R.C., Sucic, N.T., Terleckyj, O.D., Young, J.M., 2004, Bacterial Communication ("Quorum Sensing") via Ligands and Receptors: A Novel Pharmacologic Target for the Design of Antibiotic Drugs, J. Pharmacol. Exp. Ther., Vol. 312, No. 2

Rumbaugh, K.P., Griswold, J.A., Hamood, A.N., 2000, The Role of Quorum Sensing in The in Vivo Virulence of Pseudomonas aeruginosa, Microbes. Infect., 2:1721-1731 
Siswandono, Soekardjo, B., 2000, Kimia Medisinal, Airlangga University Press, Surabaya, pp 12

Susianti, S., 1996, Peran Baleng la (Litsea cubeba) Sebagai Tumbuhan Obat dan Aroma pada Masyarakat Dayak Kenyan di Pujungan Kalimantan Timur, Prosiding, Simposium Nasional Tumbuhan Obat dan Aromatik, 634-639
Vuong, C., Gerke, C., Somerville, G.A., Fischer, E.R., Otto, M., 2003, Quorum Sensing Control of Biofilm Factors in Staphylococcus epidermidis, J. Infect. Dis., 188:706718

Zhang, W., Hu, W.F., Lu, W.W., Zhao, Q.C., Shi, G.B., 2012, Antibacterial, Antifungal and Cytotoxic Isoquinoline Alkaloids from Litsea cubeba, Molecules, 1;17(11):12950 
18| Tho'atun Ma'rufah 